\title{
Should I Stay or Should I Go? Determinants of Evacuation upon Flood Warning among Households in a Flood Prone Area in Bukidnon, Philippines
}

\author{
Michael Arieh P. Medina* and Jackielyn M. Moraca \\ Department of Environmental Science \\ College of Forestry and Environmental Science \\ Central Mindanao University \\ University Town, Musuan, Bukidnon, Philippines \\ email address: mapmedina@cmu.edu.ph
}

Keywords: Disaster risk reduction, flood evacuation, logistic regression, Philippines

\begin{abstract}
To identify factors that influence the decision to evacuate upon flood warning by authorities, a study was conducted in a flood prone area in the province of Bukidnon in the Philippines. A survey of flood victims was conducted in Batangan Village, Valencia City, Bukidnon, Philippines wherein 150 respondents were interviewed. Logistic regression analysis was done to test the socio demographic factors that could influence a family's decision to either evacuate or stay upon advice by government authorities. College education, presence of children in the home, poverty, and extent of flood experienced were found to significantly influence the decision of the family to evacuate. Based on this information, the study provides recommendations for disaster managers in case of future flood incidence in the area.
\end{abstract}

\section{INTRODUCTION}

The Pulangui River in Bukidnon Province, Philippines for several times in the past years has overflowed and flooded several riverbank communities along its path. This frequent flooding in the country is believed to be caused by global factors (climate change, deforestation, biodiversity loss) as well as local factors such as improper land use and human settlements near riverbanks [1]. Floods have been affecting the lives of poor communities living near rivers. To address this, several mitigation strategies have been proposed in the form of structural [2] and non structural measures [3] as well as the combination of both [4]. However, financial and social factors made the said measures difficult to implement especially in poor communities near rivers.

Given the above facts, it is thus at least beneficial especially to disaster managers to reduce flood risk by enhancing flood response such as rapid evacuations during floods. However, residents differ in how they interpret the seriousness of flood warnings, thus, not all of them respond immediately towards evacuation [5,6]. This makes the impact of flood worse as it leads to the loss of lives which could have been avoided through evacuation.

What factors influences families to evacuate upon flood warning? In this paper, we evaluate the socio-demographic variables affecting the response of families once they are told by authorities to evacuate before a flood occurrence. This paper also recommends strategies for disaster managers to implement for the improvement of services to future flood evacuees.

\section{MATERIALS AND METHODS}

Study Area. The study was conducted in Barangay Batangan in Valencia City Bukidnon, Philippines. This barangay (village) is found along the banks of Pulangui River, the longest river in the island of Mindanao, Philippines. The area has been considered locally as one of the flood prone areas in Bukidnon [7]. 
The Respondents. The respondents of the study are composed of a purposive sample of 150 flood victims during the December 27, 2011 flood incident in Barangay Batangan. Based on the data from the Local Disaster Risk Reduction and Management Council of Valencia City, 919 residents were officially considered as flood victims in Barangay Batangan. The 150 respondents were chosen based on the following criteria: a) they were officially declared as flood victims during the 2011 flood based on the official list from the Local Disaster Risk Reduction and Management Council of Valencia City, and b) they have been residing in the area for at least 5 years.

Data Gathering. A researcher designed questionnaire was constructed and pre tested to ensure the comprehensibility of questions, convenience of respondents, and optimal duration of the interview. A face to face interview was employed to better facilitate the data gathering process. The survey was conducted during the months of November and December in 2014.

Data Analysis. To describe the socio-demographic characteristics of the respondents as well as their household features and flood experiences, the mean, frequency counts and percentage were used in analyzing the data. Binary logistic regression analysis was then utilized in testing for the relationships between the socio-demographic characteristics of the respondents as independent variables and flood evacuation behavior $(0=$ stayed; $1=$ evacuated $)$ as dependent variable.

\section{RESULTS}

Characteristics of the respondents. As shown in Table 1, most of the respondents are female (56\%) compared to males (44\%). Their average age is 45 years old, the youngest being 35 while the oldest is 78. Majority of the respondents are either high school level or high school graduate (62\%) while almost $1 / 4(23.3 \%)$ are either college level or college graduate and a few are either elementary level or elementary graduate $(14.7 \%)$.

The average household size is around 6 family members which range from 1 to 10 members in a household. The average household monthly income of the respondents is 8,287.33 pesos or $\$ 180$ which range from 1,500.00 pesos (\$33) to 36,000.00 (\$780). Almost half of these respondents have children below 5 years old in their households (41.3\%). However, only a few have family members above 60 years old (14.7\%). On the average, the respondents have resided in the study area for around 14 years which ranges from 5 years to 25 years.

In terms of housing characteristics, majority has houses with concrete floors $(80 \%)$, the rest have either floors made wood or made of packed soil. More than half (56.7\%) have walls made of concrete while the rest have wooden walls. Majority or $90 \%$ of the respondents have one-storey houses, while the remaining $10 \%$ have two storey houses.

Table 1. Socio-demographic characteristics of the respondents and their households $(\mathrm{N}=150)$

Characteristics

Description

Value

$\operatorname{Sex}[\%]$

Male

44

Female

Age [in years]

Mean

Minimum

Maximum

78

Highest educational attainment in the family [\%]

Elementary Level

4.0

Elementary Graduate

10.7 


\begin{tabular}{|c|c|c|}
\hline & High School Level & 24.7 \\
\hline & High School Graduate & 37.3 \\
\hline & College Level & 18.0 \\
\hline & College Graduate & 5.3 \\
\hline \multirow[t]{3}{*}{ Household size [number] } & Mean & 5.71 \\
\hline & Minimum & 1 \\
\hline & Maximum & 10 \\
\hline \multirow[t]{3}{*}{ Monthly income [Pesos] } & Mean & $8,287.33$ \\
\hline & Minimum & $1,500.00$ \\
\hline & Maximum & $36,000.00$ \\
\hline \multirow[t]{2}{*}{ Household with children $<5$ years old [\%] } & No Children $<5$ yrs & 58.7 \\
\hline & With Children $<5$ yrs & 41.3 \\
\hline \multirow[t]{2}{*}{ Household with members $>60$ years old $[\%]$} & No Members $>60$ yrs & 85.3 \\
\hline & With Members $>60$ yrs & 14.7 \\
\hline \multirow[t]{3}{*}{ Residency [in years] } & Mean & 13.5 \\
\hline & Minimum & 5 \\
\hline & Maximum & 25 \\
\hline \multirow[t]{2}{*}{ Housing floor materials $[\%]$} & Wood & 20.0 \\
\hline & Concrete/Tiles & 80.0 \\
\hline \multirow[t]{2}{*}{ Housing wall materials [\%] } & Wood & 43.3 \\
\hline & Concrete & 56.7 \\
\hline \multirow[t]{2}{*}{ No. of floors (number) } & 1 floor & 90.0 \\
\hline & 2 floors & 10.0 \\
\hline
\end{tabular}

Flood experiences of the respondents. As shown in Table 2, the average flood depth experienced by the respondents is $\sim 0.82$ meters ranging from 0.40 meters to 1.04 meters. The respondents experienced flooding for an average of 10.25 hours. However, some respondents have experienced flooding as short as 3 hours to an extreme of 48 hours of being inundated. Upon flood warning by the local government unit, $34 \%$ of the respondents stayed on their homes while $66 \%$ evacuated to nearby evacuation centers while some stayed in relative's houses situated in non-flood prone areas. 
Table 2. Characteristics of respondents' flood experiences $(\mathrm{N}=150)$

\begin{tabular}{lll}
\hline Characteristics & Description & Value \\
Depth of flood experienced [meters] & Mean & 0.82 \\
Duration of flood experienced [hours] & Minimum & 0.40 \\
& Maximum & 1.04 \\
Evacuation behavior during flood [\%] & Mean & 10.25 \\
& Minimum & 3 \\
& Maximum & 48 \\
\hline
\end{tabular}

Logistic regression model of evacuation behavior of respondents. In Table 3 , a model for explaining the evacuation behavior (stayed/evacuated) of the respondents was formulated using binary logistic regression analysis. Using forward conditional method, the resulting model showed that four variables significantly influence how the respondents responded to flood warning by authorities. The following are the significant determinant variables: College education, having children below 5 years, poverty or having a monthly income below PHP 5,000 (around \$110), and depth of flood experienced. All of the mentioned independent variables positively influence evacuation behavior.

Table 3. Results of logistic regression analysis with evacuation behavior $(0=$ stayed; $1=$ evacuated $)$ as dependent variable

\begin{tabular}{lcccc}
\hline \multicolumn{1}{c}{ Determinants } & B & $\begin{array}{c}\text { Wald } \\
\text { Statistics }\end{array}$ & p-value & Exp (B) \\
College education & 0.703 & 3.183 & 0.074 & 2.019 \\
Having children below 5 years & 0.672 & 3.314 & 0.069 & 1.959 \\
Poverty & 0.792 & 3.097 & 0.078 & 2.208 \\
Depth of flood experienced & 5.200 & 10.276 & 0.001 & 181.351 \\
\hline
\end{tabular}

Based on the exponentiated logistic coefficient $[\operatorname{Exp}(B)]$, respondents with college education (college level and college graduates) are 2 times more likely to evacuate than those without college education (elementary level to high school graduates). Those respondents with children below 5 years old are 1.9 times more likely to evacuate than those without children below 5 years old. At the same time, respondents with monthly income below 5,000 pesos are more likely to evacuate than those with monthly income above 5,000 pesos. The mentioned variables are significant determinants at $90 \%$ confidence level. Furthermore, those households who experiences deeper inundation are the ones more likely to have evacuated compared to those who experienced shallower floods. In fact, every meter of inundation leads to 181 times more probability of evacuation. This is significant at $99.9 \%$ level of confidence. 


\section{DISCUSSIONS}

The above results, verified some determinants of flood evacuation behaviors of respondents as previously revealed in past studies. Households with children have been found to be more likely to evacuate upon warning of upcoming natural disasters such as hurricane [8] as well as flooding [9]. Consequently this information requires incorporation into disaster management specifically through provision of transportation assistance during evacuation (families with children usually are more difficult to evacuate). This fact also necessitates the proper accommodation of children in evacuation areas because such require special needs compared to adults.

Educated respondents were found also to be more likely to evacuate. Consequently, owing to the fact that most of them are more likely to stay with friends or families in non flooded areas [10], this would somehow benefit in such a way that this will decongest evacuation shelters. This could mean that disaster managers can focus more on serving the needs of the low income group that usually go to these shelters.

Previous studies have found out that one of the viable factors that could persuade families to evacuate is the reality of the risk being conveyed $[5,6]$. The belief that one's own house is prone to flooding greatly influences a household's decision to evacuate [11]. Thus, this could probably be the reason why those who experienced deeper floods, in the case of the study, are the ones who are more likely to evacuate. It is probable that they have already experienced previous flooding in the area which leads them to believe that the threat is real upon warning by authorities. In the case of disaster managers, it is thus, essential that such threats be communicated effectively to residents. This could be done in the form of information, education, and communication activities relaying the reality of the threat to communities. Modern technology which leads to the generation of hazards and risk maps is indeed important in realizing this goal. Furthermore, the reliance of residents on mainstream media specifically on assessing the reality and risk of incoming natural disasters [12] should be further exploited by government authorities through the development of partnerships with media organizations to effectively realize such goal.

\section{CONCLUSIONS}

It was found out that college education, having children below 5 years in the household, poverty, and depth of flood experienced positively influences a family's decision to evacuate upon flood warning in the study area. Such results verify conclusions from previous studies of the same nature. These information suggests certain policy/program interventions to further enhance services to future flood evacuees in the area.

\section{Acknowledgements}

Dr. Jose Hermis P. Patricio and Forester Alex S. Olpenda of the College of Forestry and Environmental Science in Central Mindanao University both contributed extensively to the success of the study. Furthermore, this study wouldn't have been possible without the cooperation of the household respondents from the study area. 


\section{References}

[1] G. Bankoff. 2003. Constructing Vulnerability: The Historical, Natural and Social Generation of Flooding in Metropolitan Manila. Disasters. 27(3):95-109.

[2] L. Hsieh, M. Hsu, M. Li. 2006. An Assessment of Structural Measures for Flood-prone Lowlands with High Population Density along the Keelung River in Taiwan. Natural Hazards. 37:133-152.

[3] E.L. Kick, J.C. Fraser, G.M. Fulkerson, L.A. McKinney, D.H. De Vries. 2011. Repetitive flood victims and acceptance of FEMA mitigation offers: an analysis with community-system policy implications. Disasters. 35(3):510-539.

[4] Z.W. Kundzewicz, K. Takeuchi. 1999. Flood protection and management: quo vadimus? Hydrological Sciences Journal. 44(3):417-432.

[5] R.W. Perry. 1979. Evacuation Decision-Making in Natural Disasters. Mass Emergencies. 4:2538.

[6] N. Dash, H. Gladwin. 2007. Evacuation Decision Making and Behavioral Responses: Individual and Household. Natural Hazards Review. 8(3):69-77.

[7] M.A.P. Medina, J.G. Arche. 2015. The value of flood risk reduction in selected communities near the Pulangui river in Bukidnon, Philippines. Journal of Biodiversity and Environmental Sciences. 6(3):84-90.

[8] D. Solis, M. Thomas, D. Letson. 2010. An empirical evaluation of the determinants of household hurricane evacuation choice. Journal of Development and Agricultural Economics. 2(3):188-196.

[9] S.E. Heath, P.H. Kass, A.M. Beck, L.T. Glickman. 2001. Human and pet-related risk factors for household evacuation failure during a natural disaster. American Journal of Epidemiology. 153(7):659-665.

[10] J.C. Whitehead, B. Edwards, M.V. Willigen, J.R. Maiolo, K. Wilson, K.T. Smith. 2000. Heading for higher ground: factors affecting real and hypothetical hurricane evacuation behavior. Environmental Hazards. 2:133-142.

[11]E.J. Baker. 1991. Hurricane evacuation behavior. International Journal of Mass Emergencies and Disasters. 9(2):287-310.

[12]K. Dow, S.L. Cutter. 1998. Crying wolf: Repeat responses to hurricane evacuation orders. Coastal Management. 26(4):237-252. 